\title{
Barrier Device
}

National Cancer Institute

\section{Source}

National Cancer Institute. Barrier Device. NCI Thesaurus. Code C49838.

A structure or object that impedes free movement. 